ニック室に対して有効であるとの結論に達した。

\section{7. 透過線量計を用いた肺補正の検討}

大阪府立羽曳野病院放射線科

○藤岡富雄・桜井 誠

(目的) 当院は呼吸器の専門病院で放射線治療では肺 癌が主である。特に肺癌の治療には正確な病巣線量が要 求される。すでに京都大学より第41回に透過線量法に関 する報告がありわれわれは透過線量法を肺補正に用いる べく検討したので報告する.

〔方法〕厚み精度および TPR の比較, 初回時の誤差 を少なくするために線量分割する方法を検討した。

〔結果〕厚み精度, TPR ともほぼ満足でき, 線量分割 による誤差も少なかった。

〔考察, 結論〕 線量分割する方法は初回時の照射線量 誤差を少なくできるが, 計算所要時間の短縮等も今後症 例を増やしながら検討を加えていきたい。

\section{8. 腹部臟器の標的容積の検討（第 1 報 膵臓領域の線 量分布)}

\section{滋賀医科大学医学部附属病院放射線部 ○近藤康雄・橋本惠次・高橋雅文 雄川恭行}

脺癌の放射線治療は，線量を制約する肝荿，腎葴，筒 髄などの臟器の耐容範囲内で十分な線量を病巣に与える ために術中照射, 原体照射, 小線源刺入 $\left({ }^{125} \mathrm{I},{ }^{198} \mathrm{Au}\right)$, 粒子線治療，高エネルギーX線と電子線を併用した多門 照射等が試みられている，当施設では，術中照射，原体 照射等はできないので, $15 \mathrm{MV}$ X線と $20 \mathrm{MeV}$ 電子線を 併用した多門照射を行い根治線量70 Gy に対し前方より $15 \mathrm{MV} X$ 線（30\%)，20 MeV 電子線（30\%）の mixed beam で両側方より $15 \mathrm{MV} \mathrm{X}$ 線 $(20 \%, 20 \%) 60^{\circ}$ wedge で，照射すると肝臓のほとんどが50\%以下に，脊髄，腎 臟は $30 \%$ 以下に㧍さえられ，耐容範囲内で十分な線量を 病巣に与えることができた。

\section{座長集約}

演題16は漏洩中性子線の低減対策として,ターダット 材質をタングステンから銅に交換し，迷路内にボロン入 の遮蔽屝を設け，充分な効果が得られたと報告した。中 性子の漏洩は近年問題になっており，遮蔽対策も幾つか 報告されている.今回もその一つであるが, 短期工事 $(1.5$ 日）と低コスト（150万円）に着目する点がある。

質問 (大阪成人病 秦) ターゲット交換により漏洩 線量が25\%減少したが, 装置の最大線量率への影響はど うか.

答 ターダット (銅) を厚くして出力効率をあげたの
で，エネルギーは減少せず線量率は交換前と同じです。

質問 （滋賀医大 雄川） 線束中の中性子測定はどう 加.

答 測定していない.遮蔽計算指針では X線の約 0.025 \%としている.

演願17は透過線量計を用いて, 不均質部 (胸部) に対 する照射時の水等価厚変換の精度を検討した. 肺補正に ついては，照射線量の誤差を少なくする意味から初回に 線量分割を行い，臨床に応用できると報告した。不均質 部（肺）に対する補正法は，今日まで種々報告されてい る. 透過線量法は体厚ならびに不均質部の補正としての 精度は充分であるが, 異なった病巣深度で同一の補正值 が用い得るかとの問題が残る. 今後の検討を期待する.

質問 (大阪成人病 川辺) CT 像 (CT 密度) 上り求 めた厚み補正（肺補正）との違いはどうか.

答 $\mathrm{CT}$ 像より求めると呼吸位相等で $\mathrm{CT}$ 值が変動す るが分割照射することで，平均化した值になると考える． 演題18は腹部臟器の標的線量についての検討である。 外部照射では問題の多い膵臟領域において, X線（15 MV) と電子線 $(20 \mathrm{MeV})$ を組み合わせ, なおかつ重要 臟器（肝, 腎, 脊䯠）の耐容線量も考慮した興味深い線 量分布を, 報告した。治療計画上で必要なことは, 標的 容積, 治療容積, 照射容積を確実に把握して可及的に標 的に限局した線量分布を作成することである。近年この 領域には術中照射や原体照射が試みられているが，工ネ ルギーの高い装置であれば，外部照射でも良好な分布を 得ることが判明した。しかし，このような装置をもつ施 設が限られていることも現状である。

撮影-3

座長 平山伸一（兵庫医大）

19. 国産 C 社フィルムチェンジャの使用現状 大阪大学医学部附属病院

○高橋由起子 - 中西省三

〔目的〕国産C社高速フィルムチェンジャの使用経験 について全国のC社フィルムチェンジャ保有施設にアン ケート調查を行った。

〔方法〕1986年12月末までに設置されたC社フィルム チェンジャ保有施設345施設にアンケートを配布した。使 いやすさ, トラブル発生情況，使用状態等について質問 した.

〔結果〕回収率65.6\%であった。大体においてトラプ ルも少なく，使いやすいといった回答が得ら杖。，改良 すべき点としては，音が大きい，マガジンが重い，ふた があきやすいといった回答がよせられ，またメンテナン 
スについては定期点検実施の声が多く, ユーザとメーカ の連絡を密にしたいという要望も多かった。

20.デーライトシステムの適正配置について

大阪拊立羽曳野病院放射線科

○山口道弘・藤岡富雄・谷口義則

樋口勝已・桜井 誠・錦織光司

大西剛史

小西六写真工業 K.K 又野成昭

〔目的〕業務内容の変化によるデーライトシステム (サクラレシーブサプライヤーRS) の適正配置について $\mathrm{QC}$ 手法を用い種々検討を加えその指針を考えたので報 告する。

〔方法〕RSの現在位置における業務変化前と後での 作業量，導線等を比較し，次に効率的配置場所を知る心゙ く検討を加えた。

〔結果〕業務内容の変化に伴う RS の適正な配置場所 を推定することができ，その位置では従来の位置に比べ て作業量を $5.7 \%$ 効率化することができた。

〔考察〕1.QC 手法を用いることにより作業内容変化 に伴う適正な配置場所の推定が可能となった。 2.今後予 算, 部屋の作業環境等の問題が解決すれば，推定できた 適正位置に RS を設置変更する予定である。

\section{1. 各種断層撮影装置の総合比較}

大阪大学医学部附属病院中央放射線部

○森本高弘・三春方吉・中西省三

〔目的〕当病院の多軌道断層写真の画質が他施設に比 較してどのように違うか, 改良点があるのかを知る目的 で 6 施設の協力を得て比較検討した.

〔結果〕断層写真の画質に大きく影響を与える解像力 が, 他施設に比べ, 当施設が劣った. その理由はFFDが 大きく，大焦点を選ばざるを得ず，また FFD が常に一定 であるため，应大率が大きくなるからである．また他の 施設の類似装置も当施設と同等であった。つまり, 解像 力が断層撮影装置の固有なもので決定することがわかっ た。

\section{2. 長尺カセッテを用いた CR 撮影の検討について}

松下記念病院中央放射線部

○伊藤祐昭・塩谷充啓・与縄 新

楠本 修・長谷川博・佐野晃誠 中野泰彦

一般に，学童の全脊椎撮影および下肢全長撮影等は, 感度補償型増感紙と長尺カセッテとを組み合わせて撮影 を行っている、しかし，このシステムにおいては，画質， 被曝線量，撮影条件等に問題があるように思われる.特
に, 学童の全脊椎撮影時の被曝線量は, 非常に問題とな る。そこで, FCR システムで六切のIP を利用し撮影を行 つた結果，画像を縮少させることなく，実寸大で表示す ることが可能となり，また，全体に適正濃度を得ること ができ，画質の低下もみられなかった，FCR システムに よる全脊椎撮影は, 従来のシステムに対して画質を低下 させずに被曝線量を低隇することが可能となり，学童の 全瓷椎撮影等には，非常に有効な撮影手段であった。

23. ROC 解析による CRT モニ夕の経時的变化の評価 大阪大学医学部附属病院中央放射線部

○本田育子・松本 貴・ 三木 弘

森 嘉信

〔目的〕 CR P PACSの普及によって,CRTによる読 影診断が一般化していくと考える.われわれはCRTの 少化が診断にどう影響するかを ROC 解析法を用いて検 討した。

【方法]信号十雑音を47枚, 雑音のみを47枚の計94枚 の試料画像をデジタル化して，使用時間の異なる 3 台の CRT に映し， ROC解析法による 5 段階評定実験を行つ た。

〔結果〕 ROC曲線より，信号検出能は新しいCRT の 方がよかった。この要因の多くは CRT の輝度コントラ ストによると考える。

〔まとめ〕 CRT の劣化は診断能に大きく影響する。 CRTを最適な状態で使用するためには，客観的に効率よ く品質管理する方法を確立すべきである。

\section{座長集約}

このセクションでは多様の演題があったにもかかわら ず，質疑の少ないものとなり，今後の発表内容の再検討 が必要と感じられた。

演題19では，C社フィルムチェンジャーの使用アンケ 一トの集約で, 全国226とかなり広範囲の施設から数多く の意見をまとめていた。この種のアンケート調査は技師 側の不満を言うにとどまりがちだが，ぜひ次機種の開発 のためにもメーカ側にも反映させてもらいたい。

演題20では，43回総会に続き，日常業務内容とR.Sの 位置関係を QC 手法に基づき, 技師の作業量から効率的 配置を探しだされていたが，現実には撮影室・自現機等 の配管の関係上，デーライトシステムの配置を最適な場 所へ移動するのは困難であり,一施設のみの効率化にと どまる. 今後, 定量・定性的な規格化および標準化が望 まれる。

演題21では，各 6 社の代表的多軌道断層装置の総合比 較をした結果, 断層画像の最も影響する因子は, FFD と 